\title{
MNX1 Gene
}

National Cancer Institute

\section{Source}

National Cancer Institute. MNX1 Gene. NCI Thesaurus. Code C97559.

This gene plays a role in both the regulation of transcription and DNA binding. 